\title{
Factors affecting arbuscular mycorrhizal fungi of Chilean temperate rainforests
}

\author{
César Marín ${ }^{1 *}$, Paula Aguilera ${ }^{2}$, Fritz Oehl $^{3,4}$, Roberto Godoy $^{1}$
}

${ }^{1}$ Instituto de Ciencias Ambientales y Evolutivas, Universidad Austral de Chile, 5090000 Valdivia, Chile. ${ }^{2}$ Center of Amelioration and Sustainability of Volcanic Soils. BIOREN-UFRO, Universidad de La Frontera, P.O. Box 54-D, 4780000 Temuco, Chile. ${ }^{3}$ Agroscope, Ecotoxicology, Schloss 1, CH-8820 Wädenswil, Switzerland. ${ }^{4}$ Departamento de Micologia, CCB, Universidade Federal de Pernambuco, Av. da Engenharia s/n, Cidade Universitária, 50740-600,2611606 Recife, PE, Brazil. ${ }^{*}$ Corresponding author: cesarmarin@postgrado.uach.cl

\begin{abstract}
While arbuscular mycorrhizal (AM) fungi in Chile have been widely documented in agro-ecosystems, there is a knowledge gap regarding AM fungal diversity in Chilean temperate rainforests. AM fungal communities of these forests are affected by several factors: the mountain systems of Chile (Coastal Range or Andes Mountains), the mycorrhizal dominance of the forest (either ectomycorrhizal -EM- or AM), soil chemistry, and altitude. We tested the effects of mountain system, mycorrhizal dominance, soil chemistry, and altitude on AM fungal diversity. From 7,120 AM fungal spores recovered, we identified 14 species, that were found in 41 soil samples collected from 14 plots located in EM and AM forests of the Coastal Range and Andes Mountains of Southern Chile. Mountain system and mycorrhizal dominance affected AM fungal community composition, although neither fungal richness nor abundance were affected. Soil Olsen available $\mathrm{P}, \mathrm{Ca}, \mathrm{Mg}$, and $\mathrm{Na}$ were the edaphic variables structuring AM fungal community composition. There was no relationship between altitude and AM fungal richness, however at high altitudes there was higher abundance. Finally, with this and other studies, a total of 59 AM fungal species, many of which were previously registered exclusively in agroecosystems, are registered on the Chilean AM fungal species list.
\end{abstract}

Keywords: Atitude, arbuscular mycorrhizal fungi taxonomy, Chilean mountain systems, forest mycorrhizal dominance, soil chemistry, temperate rainforests 


\section{Introduction}

Arbuscular mycorrhizal (AM) fungi, contained within the subphylum Glomeromycotina, are obligate symbiotic partners of up to $82 \%$ of land plants (Davison et al., 2015). This symbiosis is crucial for the plant communities' health and the functioning of nutrient cycles at the ecosystem level (Castillo et al., 2006; Etcheverría et al., 2009). A recent review (Castillo et al., 2016) shows that for Chile, 57 AM fungal species have been reported, yet these have mainly been documented in agroecosystems (as reported elsewhere, e.g. Aguilera et al., 2014, 2015). There is an important lack of knowledge about AM fungal species presence and community dynamics in Chilean native forests, particularly in southern temperate rainforests.

There are various factors that could affect the AM fungal diversity patterns of these forests. For example, the location of these forests in either the Coastal Range or the Andes Mountains could affect fungal diversity given that these mountain systems differ in terms of their geological, biogeochemical, and edaphic features (Armesto et al., 2010). Second, the type of mycorrhiza associated with dominant vegetation could also affect fungal diversity patterns. Specifically, there are four main types of forest in Southern Chile: native coniferous-dominated forest, Nothofagus spp. (angiosperm) dominated forest, hygrophile forest, and Valdivian forest (Godoy et al., 1994). Nothofagus forests are mainly ectomycorrhizal (EM)-dominated (Palfner, 2001) while the other three forest types are predominately AM-dominated (Godoy et al., 1994; Fontenla et al., 1998; Castillo et al., 2006) with subordinate plant species having EM associations. Conifers and species of Nothofagus have different altitudinal ranges spanning lowlands to the timberline (Godoy et al., 1994). Additionally, soil chemistry and altitude can greatly affect AM fungal diversity (Shi et al., 2014; Davison et al., 2015; Yang et al., 2016). Currently, base-line knowledge of diversity patterns of AM fungi of Chilean temperate rainforests, as well as how mountain system, mycorrhizal type of the dominant vegetation, soil chemistry, and altitude affect those patterns, remain unknown.

The Coastal Mountains and Andes Mountains in Southern Chile have contrasting geological histories and therefore edaphic conditions. The Coastal Mountains, which are considered a refugium for biodiversity (Armesto et al., 2010), have higher plant taxonomic and phylogenetic diversity than the Andes Mountains (Villagrán and Armesto, 2005). The bedrock of the Coastal Mountains is highly weathered (100 - 120 kyrs stand age); thus, nutrient inputs from the atmosphere are important (Kennedy et al., 2002), particularly at south of $37^{\circ} \mathrm{S}$ latitude were the Pacific Ocean plays a relevant subsidiary function in the nutrient dynamics of these forests (Kennedy et al., 2002). Meanwhile, most of the Andes Mountains were covered by glaciers during the Last Glacial Maximum (LGM); thus, young volcanic soils ( $<5$ kyrs stand age; Villagrán and Armesto, 2005) that are richer in nutrients are found in this mountain system. In terms of belowground diversity, exchange of symbiotic microorganism was likely accelerated during the LGM in the biodiversity refugia that constituted the Chilean Coastal Range (Villagrán and Armesto, 2005). The Southern Chile Andean flora -less diverse than Coastal flora- had access to richer belowground biodiversity during concentration in refugia (Villagrán and Armesto, 2005). Therefore mycorrhizal associations should not represent functional restrictions to soil nutrient limitations at Andes (Marín et al., 2016).

There are several mycorrhizal association types including AM, EM, ericoid and orchidoid mycorrhiza. 
Plant communities are usually dominated by a single mycorrhizal type (Soudzilovskaia et al., 2015). In an ecosystem, the composition of plants with differing mycorrhizal associations can affect AM fungal diversity patterns. Recently, patterns of the mycorrhizal status of vegetation have been mapped at regional and global scales (Soudzilovskaia et al., 2015; Bueno et al., 2017a). This being said, it is still unknown how mycorrhizal dominance, here defined as the mycorrhizal type associated with the dominant plant species in a forest, affects the diversity of AM fungi.

Forests of Southern Chile mainly have EM associations. Agaricales make up a large proportion of the mycorrhizal associations in Nothofagus spp. forests (Palfner, 2001), while hygrophile, Valdivian, and native coniferous forests house mainly AM fungi (Godoy and Mayr, 1989; Carrillo et al., 1992; Godoy et al., 1994; Castillo et al., 2006, 2016; Oehl et al., 2011a, 2012; Marín et al., 2016). In EM or AM dominated forests, other mycorrhizal types (either EM or AM) are not excluded; only they are found in lower proportions and are often associated with understory plants. It must be noted, however, that the influence of all of these factors- mountain system, mycorrhizal dominance, soil chemistry, and altitude- on AM fungi diversity and community structure, is dependent upon successful AM colonization and thus reproduction. Then, the effect of all those factors (mountain system, mycorrhizal dominance, soil chemistry, and altitude) must be weighted by the effect of AM fungi hyphae root colonization on AM fungi diversity.

This study targeted Chilean Coastal and Andean temperate EM and AM dominated forests and aimed at: (1) testing the effects of mountain system, mycorrhizal dominance, soil chemistry and altitude on AM fungal diversity patterns, weighting the effect of the colonization of roots by AM fungi, and (2) updating the morphological species list and available information for AM fungi of Chilean ecosystems.

\section{Materials and Methods}

\subsection{Study sites.}

A total of fourteen $30 \times 30 \mathrm{~m}$ plots were sampled (Table 1) in six sites. Two sites in the Andes Mountains (San Pablo de Tregua Nature Reserve and Tolhuaca National Park) and four sites in the Coastal Range (Alerce Costero National Park, Nahuelbuta National Park, Los Ruiles Nature Reserve, and La Campana National Park), Chile, were selected. The selected sites included the four main types of old slow-growth temperate rainforest of south-central Chile: EM dominated forest (Nothofagus spp. including N. alpina (P. et E.) Oerst., $N$. dombeyi (Mirb.) Oerst., $N$. nitida (Phil.) Krasser, $N$. alessandrii Espinosa and $N$. macrocarpa (A. DC.) F.M. Vázquez \& R. Rodr.), AM dominated forest (including the endemic conifers $A r$ aucaria araucana (Molina) K. Koch, Fitzroya cupressoides (Molina) Johnst. and Saxegothaea conspicua Lindl.), angiosperm dominated Valdivian forest (mixed broadleaf with some $N$. nitida (Phil.) Krasser trees and some Weimannia trichosperma CAV trees), forest where no single tree species was dominant, and hygrophile forest (mixed forest with some Luma apiculata (DC.) Burret and Peumus boldus Molina), where also no single tree species dominates.

\subsection{Soil sampling}

To identify AM fungal species assemblages and determine soil chemistry, bulk soil samples were taken in the 14 plots. In five randomly selected sub-sites within each plot, one $1,000 \mathrm{~g}$ soil sample was taken with a cleaned shovel after removing the $\mathrm{O}$ horizon (A horizon; approx. $20 \mathrm{~cm} \times 20 \mathrm{~cm} \times 20 \mathrm{~cm}$ ). The samples were thoroughly mixed to obtain a composite sample for each plot -a total of 14 composite soil samples were obtained. In each composite sample, 
three randomly selected root samples were separated for analysis of root colonization by AM fungi. Roots were carefully removed afterwards, and for each composite sample, three $25 \mathrm{~g}$ soil aliquots were taken for AM fungi spore isolation and determination. Another three $25 \mathrm{~g}$ soil aliquots were dried at ambient temperature and sieved to $<2 \mathrm{~mm}$ for soil chemical analysis. A total of 42 root samples, 42 soil samples for spore isolation, and 42 soil samples for soil chemical analysis were obtained from the 14 plots examined in this study.

Table 1. Locations and characteristics of plots located in temperate rainforests in Southern Chile.

\begin{tabular}{|c|c|c|c|c|c|}
\hline Site & $\begin{array}{l}\text { Plot } \\
\text { code }\end{array}$ & Coordinates & $\begin{array}{l}\text { Altitude } \\
\text { (m.a.s.l.) }\end{array}$ & $\begin{array}{l}\text { Mycorrhizal } \\
\text { dominance }\end{array}$ & Dominant tree species \\
\hline \multicolumn{6}{|l|}{ Andes } \\
\hline San Pablo & A1.EM & $39^{\circ} 36.072^{\prime} \mathrm{S} 72^{\circ} 07.099^{\prime} \mathrm{W}$ & 660 & EM & Nothofagus alpina (P. et E.) Oerst. \\
\hline de Tregua & A2.AM & $39^{\circ} 36.080^{\prime} \mathrm{S} 72^{\circ} 05.794^{\prime} \mathrm{W}$ & 770 & $\mathrm{AM}$ & Saxegothaea conspicua Lindl. \\
\hline \multirow[t]{2}{*}{ Tolhuaca } & A3.EM & $38^{\circ} 12.298^{\prime} \mathrm{S} 71^{\circ} 49.044^{\prime} \mathrm{W}$ & 1218 & EM & Nothofagus dombeyi (Mirb.) \\
\hline & A4.AM & $38^{\circ} 11.989^{\prime} \mathrm{S} 71^{\circ} 48.644^{\prime} \mathrm{W}$ & 1365 & $\mathrm{AM}$ & Araucaria araucana (Molina) K. Koch \\
\hline \multicolumn{6}{|r|}{ the } \\
\hline Alerce & C1.EM & $40^{\circ} 11.915^{\prime} \mathrm{S} 73^{\circ} 25.887^{\prime} \mathrm{W}$ & 938 & EM & Nothofagus nitida (Phil.) Krasser \\
\hline \multirow[t]{4}{*}{ Costero } & $\mathrm{C} 2 . \mathrm{AM}$ & $40^{\circ} 11.768^{\prime} \mathrm{S} 73^{\circ} 26.108^{\prime} \mathrm{W}$ & 933 & $\mathrm{AM}$ & Fitzroya cupressoides (Molina) Johnst. \\
\hline & C3.AM & $40^{\circ} 11.777^{\prime} \mathrm{S} 73^{\circ} 26.129^{\prime} \mathrm{W}$ & 928 & $\mathrm{AM}$ & Fitzroya cupressoides (Molina) Johnst. \\
\hline & C4.AM & $40^{\circ} 11.775^{\prime} \mathrm{S} 73^{\circ} 26.162^{\prime} \mathrm{W}$ & 924 & $\mathrm{AM}$ & Fitzroya cupressoides (Molina) Johnst. \\
\hline & C5.AM & $40^{\circ} 10.182^{\prime} \mathrm{S} 73^{\circ} 32.941^{\prime} \mathrm{W}$ & 673 & $\mathrm{AM}$ & Valdivian forest \\
\hline \multirow[t]{2}{*}{ Nahuelbuta } & C6.EM & $37^{\circ} 48.952^{\prime} \mathrm{S} 73^{\circ} 00.538^{\prime} \mathrm{W}$ & 1314 & EM & Nothofagus dombeyi (Mirb.) \\
\hline & C7.AM & $37^{\circ} 47.275^{\prime} \mathrm{S} 72^{\circ} 59.870^{\prime} \mathrm{W}$ & 1347 & $\mathrm{AM}$ & Araucaria araucana (Molina) K. Koch \\
\hline Los Ruiles & C8.EM & $35^{\circ} 50.033^{\prime} \mathrm{S} 72^{\circ} 30.300^{\prime} \mathrm{W}$ & 277 & EM & Nothofagus alessandrii Espinosa \\
\hline \multirow[t]{2}{*}{ La Campana } & C9.EM & $32^{\circ} 58.008^{\prime} \mathrm{S} 71^{\circ} 07.215^{\prime} \mathrm{W}$ & 1101 & EM & Nothofagus macrocarpa (A. DC.) F.M. Vázquez \& R. Rodr \\
\hline & C10.AM & $32^{\circ} 58.500^{\prime} \mathrm{S} 71^{\circ} 07.847^{\prime} \mathrm{W}$ & 580 & $\mathrm{AM}$ & Hygrophile forest \\
\hline
\end{tabular}

Valdivian forest: high abundance of Weimannia trichosperma CAV and Nothofagus nitida (Phil.) Krasser. Hygrophile forest: high abundance of Luma apiculata (DC.) Burret and Peumus boldus Molina.

\subsection{AM fungi isolation and identification}

Spores were extracted from soils using wet sieving and sucrose density gradient centrifugation (Błaszkowski, 2012). Briefly, $25 \mathrm{~g}$ of soil were passed through sieves of 500, 125 and $32 \mu \mathrm{m}$ and thoroughly washed with distilled water. The last soil portion was collected using $32 \mu \mathrm{m}$ mesh, and the soil fraction between 500 and $125 \mu \mathrm{m}$ was distributed onto plastic tubes. $25 \mathrm{~mL}$ of the spore suspensions were transferred to $50 \mathrm{~mL}$ centrifugation tubes. $25 \mathrm{~mL}$ of a $70 \%$ sugar solution were added to the bottom of the tubes, and then the tubes were centrifuged at 2,000 rpm for $2 \mathrm{~min}$. After centrifugation, the samples were decanted, washed, and transferred to Petri dishes. Spores were carefully counted under the dissection microscope at up to 400fold magnification. The number of AM fungal spores was expressed as spores in $100 \mathrm{~g}$ of dry soil. Finally, all spores found in each sample were mounted on microscope slides in polyvinyl alcohol-lactic acid glycerol (PVLG) medium mixed 1:1 (v/v) with Melzer's reagent for their taxonomic identification. The spores were classified based on the Glomeromycota system of Oehl et al. (2011b, c). Identification reports (Błaszkowski, 2012; Oehl et al., 2011b, c) and the homepage of the Swiss collection for AM fungi (SAF; http://www.agroscope.ch/saf) were also used. 


\subsection{Soil chemical analysis}

Three subsamples of each of the 14 composite soil samples were used to measure $\mathrm{pH}$ (in $0.01 \mathrm{M} \mathrm{CaCl}_{2}$ ); electrical conductivity (EC) and redox potential (Eh) were determined in a water solution $(1 / 2.5)$ at $20^{\circ} \mathrm{C}$. Percentages of $\mathrm{C}(\mathrm{C})$ and $\mathrm{N}(\mathrm{N})$ were determined using a $\mathrm{CN}$ Elemental Analyzer (Elementar, Langenselbold, Germany). Plant available P (P_a) was determined by extraction in $0.5 \mathrm{M} \mathrm{NaHCO}_{3}(\mathrm{pH} 8.5)$ and dilution $(1 / 2.5)$ in $10 \% \mathrm{HNO}_{3}$ using Inductively Coupled Plasma Optical Emission Spectrometry (ICP-OES, VARIAN, Palo Alto, U.S.A.). The cations (Al, $\mathrm{Ca}, \mathrm{K}, \mathrm{Mg}$ and $\mathrm{Na}$ ) were determined by NH4OAc $1 \mathrm{M}$ extraction (multistandards in a matrix of $\mathrm{NH}_{4} \mathrm{OAc}$ $1 \mathrm{M}, \mathrm{HNO}_{3} 10 \%$ and ultra-pure water) by ICP-OES.

\subsection{Root colonization by AM fungi}

To test the effect of AM fungi hyphae root colonization on AM fungi diversity, three root samples from each composite sample of the 14 plots were randomly selected; -care was taken to ensure that the root samples were colonized by AM fungi; the dyeing methodology of Gemma et al. (1989) was followed to verify and evaluate colonization; these methodologies are described below. Young secondary roots were cut into $1 \mathrm{~cm}$ pieces and thoroughly washed with water. To remove the cytoplasm and nuclei from the host roots, the roots were transferred to tubes where $\mathrm{KOH}(2.5 \% \mathrm{w} / \mathrm{v})$ was added. Then, the roots were incubated in this solution for $72 \mathrm{~h}$. Afterwards, the $\mathrm{KOH}$ was removed and the roots were washed with water. The water was discarded and the roots were covered with $\mathrm{HCl}(1 \% \mathrm{w} / \mathrm{w})$; the roots were incubated in this solution for $24 \mathrm{~h}$ to eliminate excess $\mathrm{KOH}$. Excess $\mathrm{HCl}$ was also eliminated by thoroughly washing the roots with water. Then, trypan blue $(0.05 \% \mathrm{w} / \mathrm{v})$ was added to the roots for 24 $\mathrm{h}$; afterwards, the trypan blue was carefully washed with abundant water. Colonization quantification was done by the grid line intersect method (Giovannetti and Mosse, 1980); specifically, roots were randomly located on Petri dishes with grid lines, where root colonization by AM fungi was quantified.

\subsection{Statistical analysis}

To test the effectiveness of AM spore sampling, species accumulation curves across soil samples and plots were calculated using the function accumresult of the BiodiversityR package (Kindt and Coe, 2005) in R 3.3.2 (R Development Core Team, 2016). To describe AM fungi diversity patterns in the 14 plots, several diversity indices accounting for alpha diversity, dominance, and evenness (Richness, S; Shannon, $\mathrm{H}^{\prime}$; Simpson, 1-D1; Inverse Simpson, D2; Evenness, J'; Berger, BP) were calculated using the function diversityresult of the BiodiversityR $\mathrm{R}$ package (Kindt and Coe, 2005). To test if mountain system, mycorrhizal dominance, or their interaction had any effect on the calculated diversity indices, mixed linear models $(\sim$ mountain system*mycorrhizal dominance, and site as a random factor to overcome spatial effects) were calculated using the lme function of the R package nmle (Pinheiro et al., 2016).

Rényi alpha diversity and evenness profiles of each plot were calculated using the function renyiresult of the BiodiversityR package (Kindt and Coe, 2005). Rényi diversity profile values (H-alpha) are calculated based on the relative abundance of each species and using a scale parameter (alpha), ranging from zero to infinity (Kindt and Coe, 2005). Rényi profiles are directly related to richness $(\mathrm{S})$ and to the Shannon $\left(\mathrm{H}^{\prime}\right)$, Simpson (D1) and Berger (BP) indices. Thus, in a Rényi profile, the $\mathrm{H}$-alpha values reflect diversity (i.e., community $\mathrm{A}$ is more diverse than community $\mathrm{B}$ if $\mathrm{A}$ is always plotted above B; Kindt and Coe, 2005). In 
the profile, community A is more diverse or has more evenness than community $\mathrm{B}$, if the former is above and never intersects with the latter.

To calculate the alpha, beta, and gamma diversity (measured as contribution to the Simpson index, 1-D1) of the plots, the function contribdiv in the $\mathrm{R}$ package vegan (Oksanen et al., 2015) was used. The function vegdist of the $\mathrm{R}$ package vegan (Oksanen et al., 2015) was used to calculate Bray-Curtis dissimilarity, an ecological distance used to generate heatmaps of the samples and species.

To identify which of the 11 edaphic variables best predict the AM fungi community composition, $\mathrm{Ca}$ nonical Correspondence Analysis (CCA) for AM fungi was conducted using the function $c c a$ of the $\mathrm{R}$ package vegan (Oksanen et al., 2015). The order of the final variables was selected using backward model selection.

\subsection{Update on AM fungi of Chilean ecosystems}

Using the information presented in Castillo et al. (2016) as a baseline, the list of AM fungal species present in different Chilean ecosystems was updated to include temperate rainforest ecosystems. In addition to Castillo et al. (2016), three more sources of information were added: Paulino (2006), Marín et al. (2016) and this study. With this information, a comprehensive list of AM fungal species presence in various ecosystems was compiled.

\section{Results}

\subsection{Soil analysis and AM fungal communities}

Contents of $\mathrm{N}$ and $\mathrm{P} \_$a were significantly affected by mountain system and mycorrhizal dominance, respec- tively (Supplemental table 1, Link: https://drive.google. com/open?id=0B6U25wfht2s1bUFTbEZTY0taM1k). Coastal N content (average of $6.200 \%$ ) was significantly lower (t-value: -2.713 , p-value: 0.053 ) than Andean N content (average of $17.383 \%$ ). Content of $\mathrm{P} \_$a was significantly higher (t-value:1.815, p-value: 0.012 ) in EM forests (average of $19.703 \mathrm{mg} / \mathrm{Kg}$ ) than in AM forests (average of $13.586 \mathrm{mg} / \mathrm{Kg}$ ). Neither mountain system, mycorrhizal dominance, nor their interaction had any effect on the remaining nine soil chemistry variables.

With 7,120 AM fungi spores sampled and identified in the 42 soil samples from 14 plots (three technical replicates by plot obtained from one composite sample by plot), the sampling effort was sufficient both at the sample level (Figure 1a) and at the plot level (Figure 1b). A total of 14 AM fungi species were identified in the 14 studied plots (Figure 2), and these species belong to six genera: six species belong to Acaulospora (Acaulosporaceae), three to Glomus (Glomeraceae), two to Claroideoglomus (Entrophosporaceae), one to Cetraspora (Gigasporaceae), one to Scutellospora (Scutellosporaceae), and one to Simiglomus (Glomeraceae). One Acaulospora and one Glomus species could potentially be undescribed species (Figure 2). The most abundant AM species, irrespective of mountain system and mycorrhizal dominance were: Glomus sp CL1, Acaulospora laevis, and Claroideoglomus claroideum (Figure 2). Interestingly, the ecological similarity represented on Figure 2 did not reflected the phylogenetic relatedness of the species -thus, species within the same genus were not grouped together by ecological distance (Figure 2). Also, plots C5.AM, C8.EM, C9.EM and C10.AM were ecologically close (Figure 2), mainly by the high abundance of Glomus sp CL1 on these plots. 

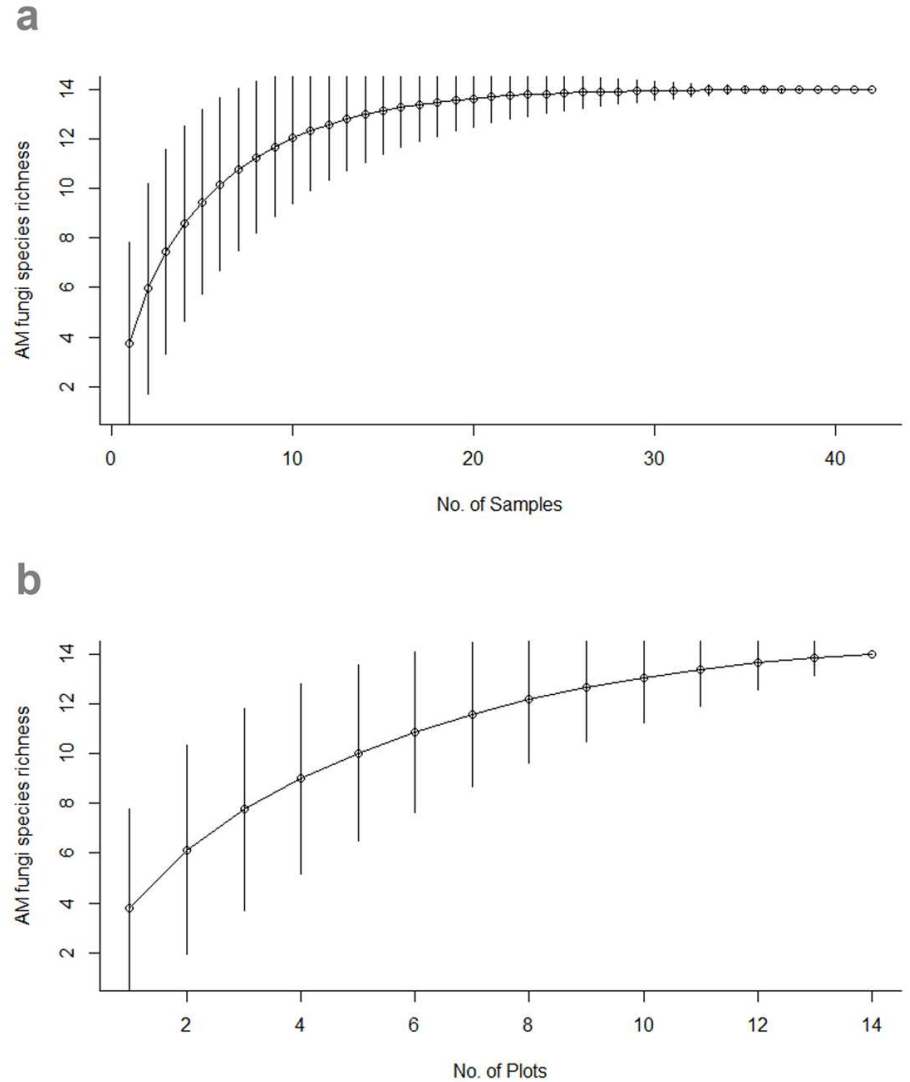

Figure 1. a. Arbuscular mycorrhizal fungi species richness accumulation curve based on number of soil samples. Bars represent permutations (1000). b. Arbuscular mycorrhizal fungi species richness accumulation curve based on number of plots. Bars represent permutations (1000). 


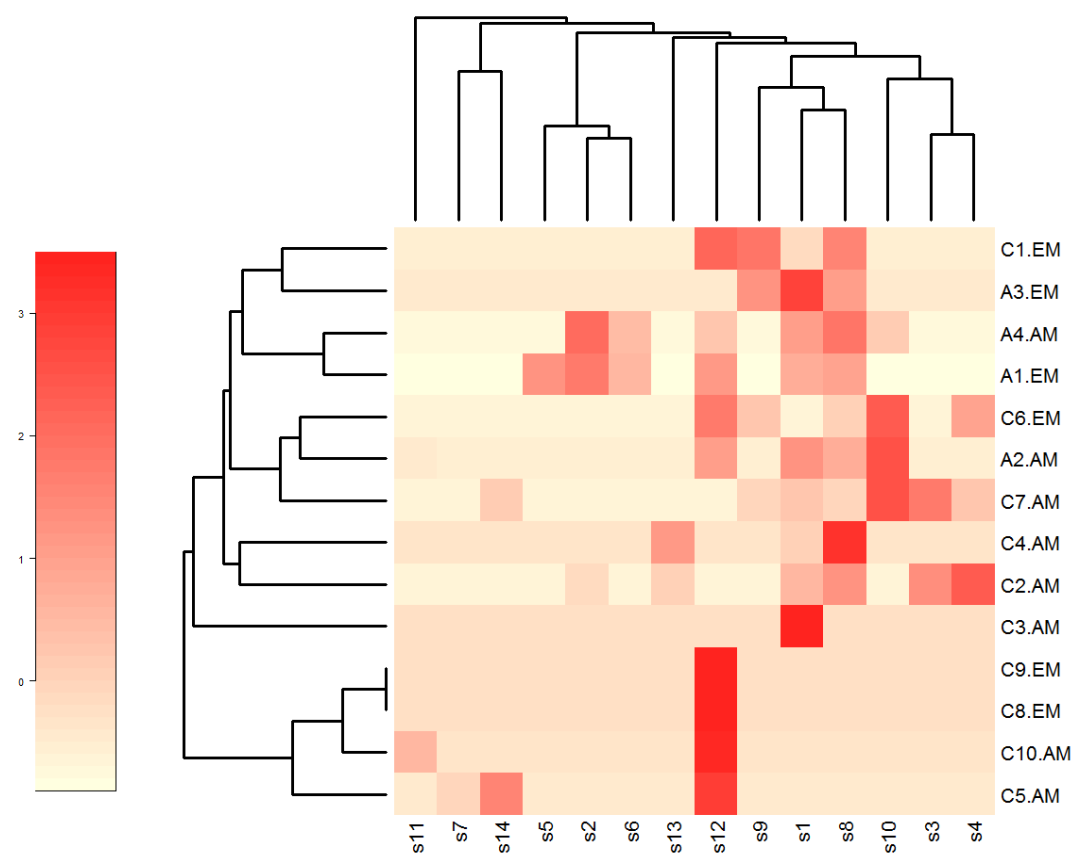

Figure 2. Heatmap and clustering (Bray-Curtis dissimilarity) of the 14 arbuscular mycorrhizal fungi species described in the 14 study plots located in temperate rainforests of Southern Chile. Species legend: s1: Acaulospora laevis, s2: Acaulospora paulinae, s3: Acaulospora punctate, s4: Acaulospora scrobiculata, s5: Acaulospora sieverdingii, s6: Acaulospora sp CL1, s7: Cetraspora gilmorei, s8: Claroideoglomus claroideum, s9: Claroideoglomus etunicatum, s10: Glomus badium, s11: Glomus diaphanum, s12: Glomus sp CL1, s13: Scutellospora calospora, s14: Simiglomus hoi.

\subsection{Effects of mountain system, mycorrhizal domi-} nance, soil chemistry, and altitude.

Richness and abundance of AM fungi was not higher solely on any of the mountain systems/mycorrhizal dominances examined: EM and AM dominated forests of both the Coastal and Andean Mountains had the highest AM fungi richness and abundance values (Supplemental table 2, Link: https://drive. google.com/open?id=0B6U25wfht2s1bkZwR3VtY mlQZWc). Meanwhile, two Coastal EM forests (C8. EM and C9.EM) located at the northern distribution of this study (Table 1) had extremely low AM fungal richness and abundance (Supplemental table 2a), when compared to Coastal AM and Coastal and Andean EM forests. These two Coastal Nothofagus forests presented extreme environmental conditions (low precipitation), and the plant cover by the ectomycorrhizal Nothofagus spp. (>95\%) was higher than in the other Nothofagus spp. plots. The diversity indices calculated also reflect this pattern (Supplemental table 2a). Furthermore, the AM fungi alpha diversity from the Rényi diversity profile (Figure $3 \mathrm{a}$ ) was also highest in EM and AM forests of the Coastal and Andean Mountains. But two plots had 0 alpha diversity, and one Coastal AM forest had the lowest AM fungi 
alpha diversity. No significant differences were seen in the Rényi evenness profile (Figure 3b) except for plot C7.AM, which was slightly less even that the other plots, and the two plots with 0 alpha diversity, which logically had complete evenness. Mountain system, mycorrhizal dominance, and their interaction did not affect any AM diversity measurement (Supplemental table $2 b$ ). The community composition of AM fungi was indeed affected by mountain system and mycorrhizal dominance; Coastal EM, Andean EM and Andean AM forests tended to have a similar AM fungal community composition (Figure 4).
Despite their proximity and having similar altitudinal and edaphic conditions to those of Coastal EM forests -with high plant cover of ectomycorrhizal Nothofagus species, within the same site Coastal AM forests had very different AM fungal community compositions (Figure 4). Despite being highly distant and contrasting in altitude (824 $\mathrm{m}$ difference), plots C8.EM and C9.EM had the exact same community composition: just species Glomus sp CL1 was present. Both Andean $\mathrm{AM}$ and EM plots had a more between and within similar community structure, given by Acaulospora and Claroideoglomus species.

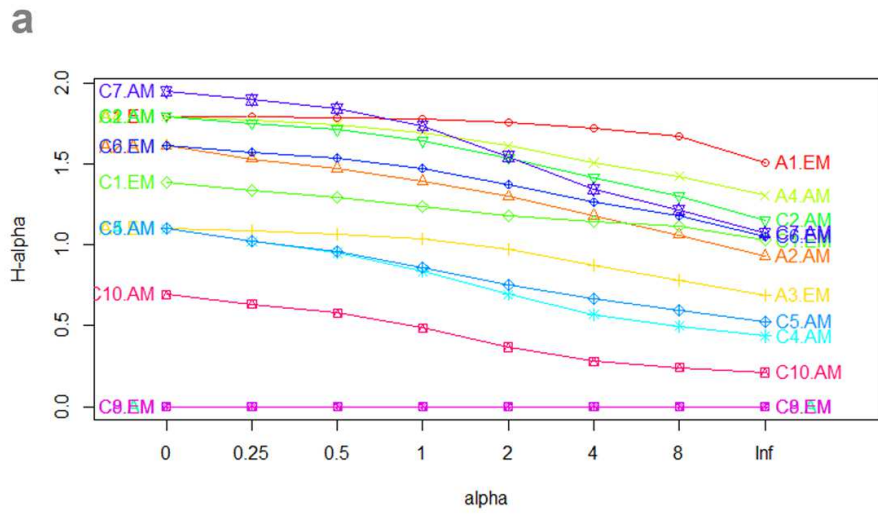

b



Figure 3. Rényi diversity and evenness profiles of arbuscular mycorrhizal fungi per plot located in temperate rainforests in Southern Chile. In a Rényi profile, community A is more diverse or has more evenness than community B, if the former is above and never intersecting with the latter. a. Rényi alpha diversity profile. b. Rényi evenness profile. 


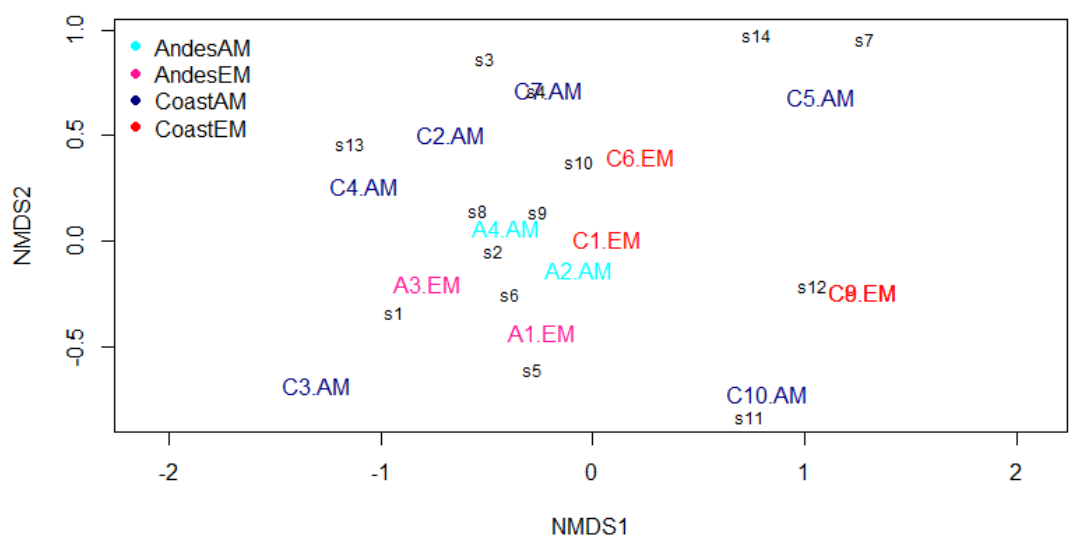

Figure 4. Non-metric multidimensional scaling (NMDS) of the arbuscular mycorrhizal fungal communities found in the 14 study plots. The plots were located in temperate rainforests in Southern Chile in either the Andes or the Coastal Mountains, and mycorrhizal dominance (AM or EM) of the forest was determined. Species legend: s1: Acaulospora laevis, s2: Acaulospora paulinae, s3: Acaulospora punctate, s4: Acaulospora scrobiculata, s5: Acaulospora sieverdingii, s6: Acaulospora sp CL1, s7: Cetraspora gilmorei, s8: Claroideoglomus claroideum, s9: Claroideoglomus etunicatum, s10: Glomus badium, s11: Glomus diaphanum, s12: Glomus sp CL1, s13: Scutellospora calospora, s14: Simiglomus hoi.

Soil P_a, Ca, Mg, and $\mathrm{Na}$ (in that order) were the main edaphic variables affecting AM fungal community compositions (Figure 5). Content of $\mathrm{P} \_\mathrm{a}$ and $\mathrm{Mg}$ had the largest effects on the AM fungal communities of Coastal EM forests while content of $\mathrm{Ca}$ and $\mathrm{Na}$ had the greatest effects on the AM fungal communities of Andean EM and AM forests (Figure 5). There was no relationship between altitude and AM fungal richness (Figure 6a), but with higher altitude there was higher AM fungi abundance (number of spores) (Figure 6b). At high altitude, abundance was highest in three of the four forest combinations examined: Coastal AM, Coastal EM, and Andean AM forests (Figure 6b). 


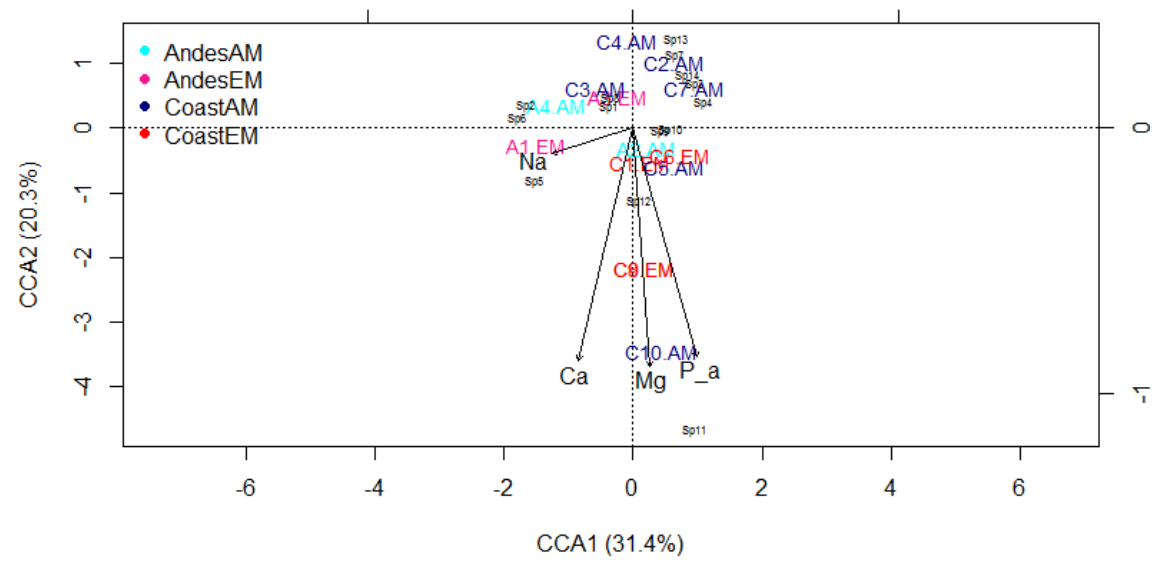

Figure 5. Canonical Correspondence Analysis (CCA) model for the arbuscular mycorrhizal fungal communities of the 14 study plots. The plots were located in temperate rainforests in Southern Chile in either the Andes or the Coastal Mountains, and mycorrhizal dominance (AM or EM) of the forest was determined. Model: $\sim \mathrm{P} \_\mathrm{a}+\mathrm{Ca}$ $+\mathrm{Mg}+\mathrm{Na}$; F: 1.741, significance: 0.039 (ANOVA for CCA, 1000 permutations; the order of the soil chemical variables was selected via backward model selection, the variance is shown in brackets).

3.3. Effect of AM root colonization on AM fungal diversity.

All the previous results were not affected by AM fungi hyphae root colonization, as neither AM fungal richness nor abundances of spores were related with root colonization by AM fungi, although the percentage of roots colonized by AM fungi was lower in Coastal AM plots (Supplemental figure 1, Link:

https://drive.google.com/open?id=0B6U25wfht2s1S U1NbVBZdWxEMTA). 

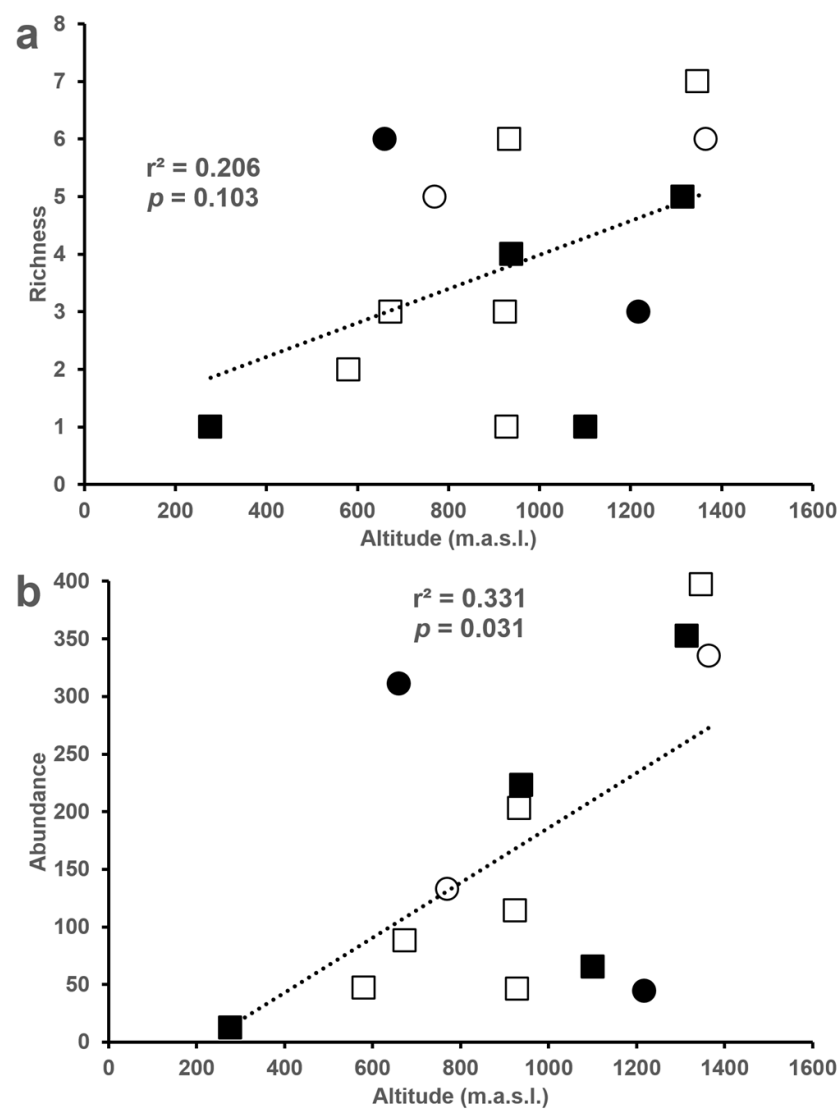

Figure 6. a. Relationship between altitude (m.a.s.l.) and arbuscular mycorrhizal fungi species richess by mountain system and by mycorrhizal dominance combination (Andes EM (•), Andes AM (०), Coast EM (•), Coast AM (口)). b. Relationship between altitude (m.a.s.l.) and arbuscular mycorrhizal fungi abundance (number of spores) by mountain

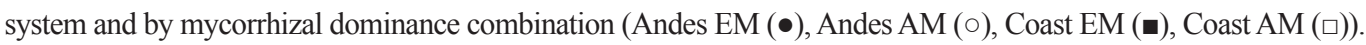

\subsection{Update on AM fungi of Chilean ecosystems}

From 57 AM fungal species registered by Castillo et al. (2016), two more species were added for a total of 59 AM fungi species, belonging to 21 genera, registered for Chile (Table 2) -a 3.5\% increase in the AM fungal species registered for Chile. Importantly, 20 registered AM fungal species found in anthropogenically intervened ecosystems (Castillo et al., 2016) were also present in pristine EM and AM forests
(Table 2) -thus, $35.1 \%$ of registered species, which were thought to be exclusive from anthropogenic environments are also present on pristine forests. Two AM fungi species recently discovered were also found on this study: Acaulospora punctata (Oehl et al., 2011a) and Ambispora reticulata (Oehl et al., 2012). These results provide new information on AM fungal species presence by ecosystem type (two new ecosystem types) and AM fungal species (two new AM fungal species). 
Table 2. Updated arbuscular mycorrhizal (AM) fungal species list for Chilean ecosystems. The majority of the information in this table can be found in Table 5 of Castillo et al. (2016); (DOI: http://dx.doi.org/10.4067/S071895162016005000036) however, two types of ecosystems were added: AM forest, which corresponds to native coniferous forests dominated by AM fungi, and high altitude Scrubland. Ectomycorrhizal (EM) forest corresponds to Nothofagus forests dominated by EM fungi. Numbers in parenthesis indicate where the information comes from: (1), Paulino (2006); (2), Marín et al. (2016); (3), this study.

\begin{tabular}{|c|c|c|c|c|c|c|c|}
\hline AM species & $\begin{array}{l}\text { AM } \\
\text { forest }\end{array}$ & $\begin{array}{l}\text { EM } \\
\text { forest }\end{array}$ & Scrubland & Grassland & Horticultural & $\begin{array}{l}\text { Wheat } \\
\text { rotation }\end{array}$ & Wheat \\
\hline \multicolumn{8}{|l|}{ *Acaulospora } \\
\hline Ac. alpinaOehl, Sýkorová \& Sieverd. (2) & & $\mathrm{X}(2)$ & & $\mathrm{X}$ & $\mathrm{X}$ & & \\
\hline Ac. cavernata Blaszk. & & & & $\mathrm{X}$ & & & \\
\hline Ac. colossica P.A. Schultz, Bever \& J.B. Morton & & $\mathrm{X}$ & & $\mathrm{X}$ & & $\mathrm{X}$ & \\
\hline Ac. dilatata J.B. Morton & & $\mathrm{X}$ & & $\mathrm{X}$ & & $\mathrm{X}$ & \\
\hline Ac. koskei Blaszk. & & $\begin{array}{l}\mathrm{X} \\
\mathrm{X}(2\end{array}$ & & $\mathrm{X}$ & & $\mathrm{X}$ & \\
\hline Ac. laevis Gerd. \& Trappe $(2,3)$ & $\mathbf{X}(\mathbf{3})$ & 3) & $X(2)$ & $\mathrm{X}$ & $\mathrm{X}$ & $\mathrm{X}$ & $\mathrm{X}$ \\
\hline Ac. longula Spain \& N.C. Schenck & & $\mathrm{X}$ & & $\mathrm{X}$ & $\mathrm{X}$ & & $\mathrm{X}$ \\
\hline $\begin{array}{l}\text { Ac. mellea Spain \& N.C. Schenck (1) } \\
\text { Ac. nivalis Oehl, Palenz., I.C. Sánchez, Kuss, }\end{array}$ & $\mathbf{X}(1)$ & $\mathrm{x}$ & & $\mathrm{X}$ & & $\mathrm{X}$ & \\
\hline Sieverd. \& G.A. Silva & & & & $\mathrm{X}$ & & & \\
\hline $\begin{array}{l}\text { Ac. paulinae Blaszk. }(2,3) \\
\text { Ac punctata Oehl Palenz IC Sánchez G A }\end{array}$ & $\mathbf{X}(3)$ & $\begin{array}{l}X(2, \\
3)\end{array}$ & & $\mathrm{X}$ & $\mathrm{X}$ & & \\
\hline $\begin{array}{l}\text { Ac. punctata Oehl, Palenz., I.C. Sánchez, G.A. } \\
\text { Silva, C. Castillo \& Sieverd. }(2,3)\end{array}$ & $\mathbf{X}(\mathbf{3})$ & $\mathrm{X}(2)$ & $\mathbf{X}(2)$ & $\mathrm{X}$ & & & \\
\hline Ac. scrobiculata Trappe $(1,2,3)$ & $X(1,3)$ & $\mathrm{X}(2)$ & & $\mathrm{X}$ & & & \\
\hline Ac. sieverdingii Oehl, Sýkorová \& Blaszk. (3) & & $\mathbf{X}(3)$ & & & & & $\mathrm{X}$ \\
\hline Ac. spinosa C. Walker \& Trappe (2) & & $\mathrm{X}(2)$ & & & $\mathrm{X}$ & $\mathrm{X}$ & \\
\hline Ac. thomii Blaszk. & & & & $\mathrm{X}$ & $\mathrm{X}$ & $\mathrm{X}$ & \\
\hline Acaulospora spp. $(2,3)$ & $\mathbf{X}(\mathbf{3})$ & $\mathbf{X}(2)$ & & $\mathrm{X}$ & $\mathrm{X}$ & $\mathrm{X}$ & $\mathrm{X}$ \\
\hline \multicolumn{8}{|l|}{ *Ambispora } \\
\hline $\begin{array}{l}\text { Am. gerdemannii C. Walker, Vestberg \& A. } \\
\text { Schüssler }\end{array}$ & & & & & & & $\mathrm{X}$ \\
\hline Am. reticulata Oehl \& Sieverd. & & $\mathbf{X}(2)$ & & & & & \\
\hline \multicolumn{8}{|l|}{ *Archaeospora } \\
\hline Ar. leptoticha J.B. Morton \& D. Redecker & & $\mathrm{X}$ & & & & $\mathrm{X}$ & \\
\hline $\begin{array}{l}\text { Ar. myriocarpa Oehl, G.A. Silva, B.T. Goto \& } \\
\text { Sieverd. (2) }\end{array}$ & & X (2) & & & & & $\mathrm{X}$ \\
\hline $\begin{array}{l}\text { Ar. trappei J.B. Morton \& D. Redecker }(1,2) \\
\text { Ar. undulata Sieverd., G.A. Silva, B.T. Goto \& }\end{array}$ & $\mathbf{X}(1)$ & $\mathrm{X}(2)$ & & $\mathrm{X}$ & $\mathrm{X}$ & $\mathrm{X}$ & $\mathrm{x}$ \\
\hline Oehl. & & & & & $\mathrm{X}$ & & \\
\hline Archaeospora spp. (1) & $\mathbf{X}(1)$ & $\mathrm{x}$ & & $\mathrm{X}$ & & $\mathrm{x}$ & $\mathrm{X}$ \\
\hline \multicolumn{8}{|l|}{ *Cetraspora } \\
\hline Ce. gilmorei Oehl, F.A. de Souza \& Sieverd. (3) & $\mathbf{X}(3)$ & & & $\mathrm{X}$ & & & $\mathrm{X}$ \\
\hline $\begin{array}{l}\text { Cetraspora spp. } \\
*_{\text {Claroideoglomus }}\end{array}$ & \multicolumn{4}{|c|}{ *Claroideoglomus } & & & $\mathrm{X}$ \\
\hline Cl. claroideum C. Walker \& A. Schüssler $(2,3)$ & $\mathbf{X}(\mathbf{3})$ & $\begin{array}{l}X(2, \\
3)\end{array}$ & $\mathrm{X}(\mathbf{2})$ & $\mathrm{X}$ & $\mathrm{X}$ & $\mathrm{X}$ & $\mathrm{X}$ \\
\hline Cl. etunicatum C. Walker \& A. Schüssler $(2,3)$ & $\mathbf{X}(3)$ & $\mathrm{X}(3)$ & $X(2)$ & $\mathrm{X}$ & $\mathrm{X}$ & $\mathrm{X}$ & $\mathrm{X}$ \\
\hline $\begin{array}{l}\text { Cl. lamellosum C. Walker \& A. Schüssler } \\
\text { *Diversispora }\end{array}$ & & & & & & $\mathrm{X}$ & \\
\hline Di. spurca C. Walker \& A. Schüssler & & $\mathrm{x}$ & & $\mathrm{X}$ & $\mathrm{X}$ & $\mathrm{X}$ & \\
\hline $\begin{array}{l}\text { Di. epigaea A. Schüssler, Krüger, C. Walker } \\
\text { *Dominikia }\end{array}$ & & & & & $\mathrm{X}$ & & \\
\hline
\end{tabular}




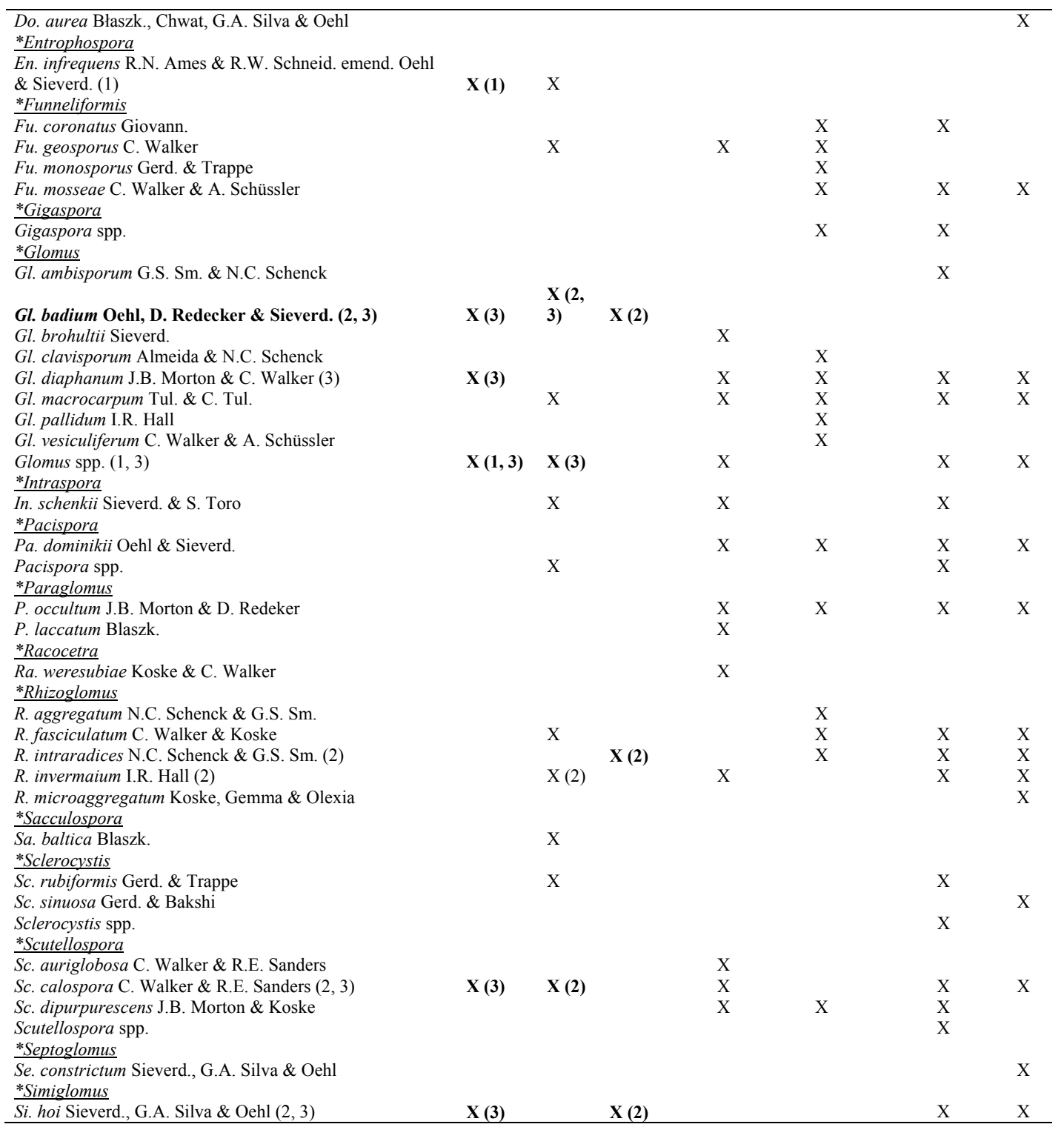

In bold: new additions (with respect to Castillo et al., 2016) of AM fungal species presence by ecosystem type and species. Two new arbuscular mycorrhizal fungi species were registered with this update. Fungal genera are underlined and preceded by an asterisk. 


\section{Discussion}

While Chilean coastal forests have greater plant diversity and are typically poorer in soil nutrients than Andean forests (Armesto et al., 2010), here we did not find any effect of mountain system on fungal richness or abundance. Rather AM community composition was affected by mountain system- a result similar to the idea proposed by Armesto et al. (2010) for microbial communities. As coastal forests served as biodiversity refugia for species originating in Andean forests, the belowground community likely recovered its original state after the reconnection of formerly glacially separated areas. Despite this, ecological interactions of microbial communities would have changed given the contrasting environments (Armesto et al., 2010). Interestingly, and contrary to our previous studies on temperate rainforests (Marín et al., 2016), the ecological similarities between AM fungal species did not correspond to its phylogenetic relatedness. Rather, this result is like what we have found on agroecosystems (Aguilera et al., 2017). Thus, while Marín et al. (2016) study was a geographically restricted study, both Aguilera et al. (2017) and this study used a broad ecosystem and geographic range, respectively. Thus, it may be possible that phylogenetic relatedness of AM species reflects also its ecological interactions only when comparing geographically close and/or similar ecosystems, while ecological functions of AM species on comparisons from distant and different ecosystems can be performed by non-related species (Davison et al., 2015).

Edaphic factors also seem to be scale-dependent: in Marín et al. (2016), when comparing closely located plots, $\mathrm{P} \_\mathrm{a}, \mathrm{pH}$ and $\mathrm{Al}$ saturation were the main edaphic factors structuring AM fungal communities, while in this study, just $\mathrm{P}$ a remained but $\mathrm{Ca}, \mathrm{Mg}$ and $\mathrm{Na}$ replaced $\mathrm{pH}$ and $\mathrm{Al}$ saturation. Could be deduced that a small scale, besides $\mathrm{P}_{-}$a, limiting edaphic fac- tors structure $\mathrm{AM}$ fungal communities, as $\mathrm{pH}$ and $\mathrm{Al}$ saturation in Marín et al. (2016), cations (Ca, Mg and $\mathrm{Na}$ ) structure these communities at a regional scale (this study), and basic nutrients ( $\mathrm{N}$ and organic C) at a global scale (Davison et al., 2015). A global study on AM fungal diversity patterns (Davison et al., 2015) shows that despite AM fungi are locally adapted, they are broadly distributed and present low endemism. Furthermore, in our study, a single non-described species (Glomus sp. CL1) was highly abundant and grouped four highly separated coastal plots (C5.AM, C8.EM, C9.EM and C10.AM), thus, reinforcing this idea, given the contrasting edaphic parameters and the distance between these plots. In our previous studies (Marín et al., 2016; Aguilera et $a l ., 2017)$ we also found that described and non-described AM fungal species grouped together highly contrasting ecosystems/treatments. Also, further studies are necessary to clarify the taxonomic status of these non-described AM fungi species.

Regarding the community structure of the studied plots, interestingly, the Andean plots grouped both between them and within EM and AM forests, and this grouping was given by six AM fungal species of the genus Acaulospora and Claroideoglomus, none of which was specifically related to a single plot. Contrastingly, both Coastal EM and Coastal AM plots had highly different community structure, except for plots C8.EM and C9.EM which had a single common species in low abundance. The community structure of Coastal plots was often given by one or two AM fungal species related to a single plot; these species belonged to all the described genus on this study. This leads to conclude that the AM fungal community structure of Andean plots -which is highly similar between and within EM and AM forests- is given by related and common species, while the Coastal AM fungal community structure -highly different between and within EM and AM forests- is given by non-related and specific species. 
This contrast between Andean and Coastal AM fungal community structures is given by edaphic parameters: while Andean communities were more related to $\mathrm{Na}$, Coastal EM Andean plots were more related to $\mathrm{Mg}$ and $\mathrm{P} \_\mathrm{a}$, and there was no clear pattern regarding Coastal AM plots. Glomus sp CL1 which grouped plots C5.AM, C8.EM, C9.EM and C10.AM, was highly related to Mg content. Meanwhile, some Acaulospora species were related to $\mathrm{Na}$ content.

Forest mycorrhizal dominance -the dominant mycorrhizal type of the forest- was related to AM fungal community composition/structure (conjunct measure of species richness and abundance) but not to AM fungal community richness or abundance. Furthermore, community structure, more than simply richness or abundance, reflects the ecological cooperative and competitive interactions within each community (Davison et al., 2015). The effects of mycorrhizal dominance on AM fungal communities needs to be further studied to clarify how 'mycorrhizal traits' (Moora, 2014) influence the total soil fungal community as well as specific fungal guilds.

The AM fungal communities were structured by several edaphic factors; a pattern that has been found in global scale studies (Davison et al., 2015). Although higher altitudes have been shown to have lower total fungal diversity (Shi et al., 2014; Yang et al., 2016), and this holds even at short elevational gradients (Marín et al., 2016), in our study AM fungal richness was not affected by altitude. Interestingly, though, AM fungal abundance (number of spores) increased with altitude irrespective of the mycorrhizal dominance of the forests or mountain system. The altitudinal range of the plots covered more than $1,000 \mathrm{~m}$, from 277 m.a.s.l. to 1,365 m.a.s.l., i.e., which is the natural altitudinal range of these forests in Southern Chile. It is worth to mention that none of these results -effects of mountain system, mycorrhizal dominance, edaphic parameters and altitude and AM fungal di- versity- seems to be affected by root colonization, as there was no relationship between the percentage of roots colonized by AM fungi hyphae and AM fungal richness and abundance. This result is in accordance with previous studies (Mafaziya and Madawala, 2015; Aguilera et al., 2017). Finally, and based on the work of Castillo et al. (2016) we updated the species list of AM fungi species in Chile. The list now includes a total of 59 species belonging to 21 genera. Interestingly, we also found that most of these species are present both in agroecosystems and in southern Chilean temperate rainforests.

\section{Conclusions}

Mountain system and mycorrhizal dominance did affect ecological interactions (composition) of AM fungi, although richness and abundance were not affected. Coastal EM and AM forests presented a highly different AM fungal community structure, where one or two single non-related species were related to a single plot and soil Mg and P_a, while Andean EM and AM forests presented a similar community structure given by related species and soil $\mathrm{Na}$. This underpins the idea that Coastal ecosystems served as a belowground biodiversity refugia (Villagrán and Armesto, 2005), as a more complex and specific AM fungal community structure is found in the Coast Mountains when compared to the Andes. Thus, this is precisely the effect of 'mountain system' on the AM fungal community structure. While less pronounced, the effect of the forest mycorrhizal dominance (EM and AM) was especially stronger in systems with almost complete EM (or AM) plant cover. There was no relationship between altitude and AM fungal richness, but with higher altitude there was higher AM fungi abundance. Finally, we updated to 59 AM fungi species registered in Chile. Future studies of AM fungi in Chile should employ metagenomic and bioinformatic methods to obtain a 
comprehensive view of AM fungal diversity in Chilean ecosystems (Bueno et al., 2017b). Furthermore, it is crucial to determine the relationships between soil chemical variables, mycorrhizal colonization, and plant diversity, to establish a broader view of ecosystem functioning.

\section{Aknowledgements}

We thank Emily Giles for her helpful comments regarding this manuscript language style. This study was partially funded by the Dirección de Estudios de Postgrado (Universidad Austral de Chile), as part a research stay scholarship in Germany (C. Marín), by CONICYT National Doctorate Scholarship No. 21150047, by the FONDECYT projects No. 1141060 and No. 3150175, and by the FONDEF project No. VIU15E0073 (P. Aguilera).

\section{References}

Aguilera, P., Cornejo, P., Borie, F., Barea, J.M., Von Baer, E., Oehl, F. 2014. Diversity of arbuscular mycorrhizal fungi associated with Triticum aestivum L. plants growing in an Andosol with high aluminum level. Agr. Ecosyst. Environ. 186, 178-184.

Aguilera, P., Cumming, J., Oehl, F., Cornejo, P., Borie, F. 2015. Diversity of arbuscular mycorrhizal fungi in acidic soils and their contribution to aluminum phytotoxicity alleviation. In: S. Panda, F. Baluška (eds). Aluminum Stress Adaptation in Plants. Springer International Publishing AG, Cham, pp: 203-228.

Aguilera, P., Marín, C., Oehl, F., Godoy, R., Borie, F., Cornejo, P.E. 2017. Selection of aluminum tolerant cereal genotypes strongly influences the arbuscular mycorrhizal fungal communities in an acidic Andosol. Agr. Ecosyst. Environ. 246, 86-93.
Armesto, J.J., Manuschevich, D., Mora, A., SmithRamirez, C., Rozzi, R., Abarzúa, A.M., Marquet, P.A. 2010. From the holocene to the Anthropocene: A historical framework for land cover change in southwestern South America in the past 15,000 years. Land Use Policy. 27, 148-160.

Błaszkowski, J. 2012. Glomeromycota. W. Szafer Institute of Botany, Polish Academy of Sciences, Kraków, 303 p.

Bueno, C.G., Moora, M., Gerz, M., Davison, J., Öpik, M., Pärtel, M., Zobel, M. 2017a. Plant mycorrhizal status, but not type, shifts with latitude and elevation in Europe. Global Ecol. Biogeogr. 26, 690-699.

Bueno, C.G., Marín, C., Silva-Flores, P., Aguilera, P., Godoy, R. 2017b. Think globally, research locally: contrasting patterns of mycorrhizal symbiosis in South America. New Phytol. 215, 1306-1309.

Carrillo, R., Godoy, R., Peredo, H. 1992. Simbiosis micorrízica en comunidades boscosas del valle Central en el Sur de Chile. Bosque. 13, 57-67.

Castillo, C.G., Borie, F., Godoy, R., Rubio, R., Sieverding, E. 2006. Diversity of mycorrhizal plant species and arbuscular mycorrhizal fungi in evergreen forest, deciduous forest and grassland ecosystems of Southern Chile. J. Appl. Bot. Food Qual. 80, 40-47.

Castillo, C.G., Borie, F., Oehl, F., Sieverding, E. 2016. Arbuscular mycorrhizal fungi biodiversity: prospecting in Southern-Central zone of Chile. A review. J. Soil Sci. Plant Nutr. 16, 400-422.

Davison, J., Moora, M., Öpik, M., Adholeya, A., Ainsaar, L., Bâ, A., Zobel, M. 2015. Global assessment of arbuscular mycorrhizal fungus diversity reveals very low endemism. Science. 349, 970-973.

Etcheverría, P., Huygens, D., Godoy, R., Borie, F., Boeckx, P. 2009. Arbuscular mycorrhizal fungi contribute to ${ }_{13} \mathrm{C}$ and ${ }_{15} \mathrm{~N}$ enrichment of soil organic matter in forest soils. Soil Biol. Biochem. 41, 858-861. 
Fontenla, S., Godoy, R., Rosso, P., Havrylenko, M. 1998. Root associations in Austrocedrus forests and seasonal dynamics of arbuscular mycorrhizas. Mycorrhiza. 8, 29-33.

Gemma, J.N., Koske, R.E., Carreiro, M. 1989. Seasonal dynamics of selected species of VA mycorrhizal fungi in a sand dune. Mycol. Res. 92, $317-$ 321 .

Giovannetti, M., Mosse, B. 1980. An evaluation of techniques for measuring vesicular arbuscular mycorrhizal infection in roots. New Phytol. 84, 489-500.

Godoy, R., Mayr, R. 1989. Caracterización morfológica de micorrizas vesículo-arbusculares en coníferas endémicas del sur de Chile. Bosque. 10, 89-98.

Godoy, R., Romero, R., Carrillo, R. 1994. Estatus micotrófico de la flora vascular en bosques de coníferas nativas. Rev. Chil. Hist. Nat. 67, 209220 .

Kennedy, M.J., Hedin, L.O., Derry, L.A. 2002. Decoupling of unpolluted temperate forests from rock nutrient sources revealed by natural $87 \mathrm{Sr} 866 \mathrm{Sr}$ and $84 \mathrm{Sr}$ tracer addition. P. Natl. Acad. Sci. USA. 99, 9639-9644.

Kindt, R., Coe, R. 2005. Tree diversity analysis: a manual and software for common statistical methods for ecological and biodiversity studies. World Agroforestry Centre, Nairobi, 196 p.

Mafaziya, F., Madawala, S. 2015. Abundance, richness and root colonization of arbuscular mycorrhizal fungi in natural and semi-natural land use types at upper Hantana. Ceylon Journal of Science (Biological Sciences). 44, 25-34.

Marín, C., Aguilera, P., Cornejo, P., Godoy, R., Oehl, F., Palfner, G., Boy, J. 2016. Arbuscular mycorrhizal assemblages along contrasting Andean forests of southern Chile. J. Soil Sci. Plant Nutr. 16, 916-929.
Moora, M. 2014. Mycorrhizal traits and plant communities: perspectives for integration. J. Veg. Sci. 25, 1126-1132.

Oehl, F., Silva, G.A.D., Palenzuela, J., Sánchez-Castro, I., Castillo, C., Sieverding, E. 2011a. Acaulospora punctata, a new fungal species in the Glomeromycetes from mountainous altitudes of the Swiss Alps and Chilean Andes. Nova Hedwigia. 93, 353-362.

Oehl, F., Sieverding, E., Palenzuela, J., Ineichen, K., Da Silva, G.A. 2011b. Advances in Glomeromycota taxonomy and classification. IMA Fungus. 2, 191-199.

Oehl, F., Da Silva, A.G., Goto, B.T., Costa Maia, L., Sieverding, E. 2011c. Glomeromycota: two new classes and a new order. Mycotaxon. 116, 365-379.

Oehl, F., Castillo, C., Schneider, D., Säle, V., Sieverding, E. 2012. Ambispora reticulata, a new species in the Glomeromycota from mountainous areas in Switzerland and Chile. J. Appl. Bot. Food Qual. $85,129-133$.

Oksanen, J., Blanchet, F.G., Kindt, R., Legendre, P., Minchin, P.R., O'Hara, R.B., Simpson, G.L., Solymos, P., Stevens, M.H.H., Wagner, H. 2015. Vegan: Community Ecology Package. R package version 2.3-1. http://CRAN.R-project.org/ package $=$ vegan

Palfner, G. 2001. Taxonomische studien an Ektomykorrhizen aus den Nothofagus-Wáldern Mittelsüdchiles. Bibliotheca Mycologica 190. Berlin, Cramer, 243 p.

Paulino, L. 2006. Efectos post-incendio sobre en el ecosistema Araucaria-Nothofagus, Parque Nacional Tolhuaca. Doctoral thesis, Universidad Austral de Chile, Chile. 186 p.

Pinheiro, J., Bates, D., DebRoy, S., Sarkar, D., R Development Core Team. 2016. nlme: Linear and Nonlinear Mixed Effects Models. R package version 3.1-128. http://CRAN.R-project.org/ package $=$ nlme 
R Development Core Team. 2016. R: A Language and Environment for Statistical Computing. The R Foundation for Statistical Computing, Vienna. Available online at http://www.R-project.org/

Shi, Z., Wang, F., Zhang, K., Chen, Y. 2014. Diversity and distribution of arbuscular mycorrhizal fungi along altitudinal gradients in Mount Taibai of the Qinling Mountains. Can. J. Microbiol. 60, 811-818.

Soudzilovskaia, N.A., Douma, J.C., Akhmetzhanova, A.A., Bodegom, P.M., Cornwell, W.K., Moens, E.J., Cornelissen, J.H.C. 2015. Global patterns ofplant root colonization intensity by mycorrhizal fungi explained by climate and soil chemistry. Global Ecol. Biogeogr. 24, 371-382.
Villagrán, C., Armesto, J.J. 2005. Fitogeografía histórica de la Cordillera de la Costa de Chile. In: C. Smith-Ramírez, J.J. Armesto, C. Valdovinos (eds). Historia, Biodiversidad y Ecología de los Bosques Costeros de Chile. Editorial Universitaria, Santiago, pp: 99-116.

Yang, W., Zheng, Y., Gao, C., Duan, J.C., Wang, S.P., Guo, L.D. 2016. Arbuscular mycorrhizal fungal community composition affected by original elevation rather than translocation along an altitudinal gradient on the Qinghai-Tibet Plateau. Scientific Reports. 6, 36606. 